\section{Letter from Field}

Check for updates

\title{
List of KOFIH development projects ongoing in 2019
}

\section{Chanju Kim, Yein Park, Chibum Shin, Hyunkyong Kim (i)}

Korea Foundation for International Healthcare, Seoul, Korea

Editor's note: Ms. Hyunkyong Kim is currently serving as the Director General, Division of International Development Cooperation at the Korea Foundation for International Healthcare (KOFIH), which is the health specific bilateral agency under the Ministry of Health, Republic of Korea.

Korea Foundation for International Healthcare (KOFIH), as a public affiliated organization of the Ministry of Health and Welfare, was founded in 2006 to inherit the dedication of late Dr. Lee Jong-wook, the $6^{\text {th }}$ Director General of World Health Organization to realize humanitarianism and global cooperation through healthcare support for developing countries, North Korea, overseas Koreans and foreign workers in Korea. KOFIH is providing healthcare support to save precious human lives regardless of sex, ethnicity, region or religion.

In response to the growing calls for official development assistance (ODA) as a leading organization to support healthcare needs in developing countries, KOFIH has not only strengthened itself, but has also changed to adapt to evolving global needs. KOFIH has become sensitive to the needs of those that we serve by establishing partnership and consulting with those who receive our assistance. With this close cooperation, KOFIH continues to strive to be a global partner towards healthcare improvement with three basic aims: sustainable development cooperation, sustainable healthcare assistance, and sustainable reform. It is our hope to reach the ultimate goal of making the world free from disease. Table 1 shows the list of KOFIH's ongoing ODA projects in 2019. 
Table 1. KOFIH 2019 official development assistance projects

\begin{tabular}{|c|c|c|c|c|c|}
\hline Region & Country & Project name & Period & $\begin{array}{l}\text { Budget } \\
\text { (USD) }\end{array}$ & Partner agency \\
\hline \multirow{3}{*}{$\begin{array}{l}\text { Asia \& } \\
\text { Africa }\end{array}$} & Multiple & Dr LEE Jong-wook Fellowship Program & 2019 & $4.4 \mathrm{M}$ & - MoH of each country \\
\hline & & & & & - EDCF \\
\hline & & & & & - KOICA \\
\hline \multirow[t]{28}{*}{ Asia } & Cambodia & $\begin{array}{l}\text { Integrated Package of Reproductive, Maternal, Newborn and Child Health } \\
\text { in the Western Region, Cambodia }\end{array}$ & 2017-2021 & $11.7 \mathrm{M}$ & $\begin{array}{l}\text { - MoH, Cambodia } \\
\text { - KOICA }\end{array}$ \\
\hline & Lao PDR & $\begin{array}{l}\text { Health System Strengthening Project Focused on Reproductive, Maternal, } \\
\text { Newborn and Child Health (RMNCH) in North-Eastern Provinces, Lao PDR }\end{array}$ & $2016-2021$ & $13.5 \mathrm{M}$ & - MoH, Lao PDR \\
\hline & & Hospital Operation and Management Consulting Project for the University & 2019-2022 & $1.8 \mathrm{M}$ & - MoH, Lao PDR \\
\hline & & & & & - EDCF \\
\hline & & Strengthening Management System of Medical Equipment in Lao PDR & 2018-2022 & $4.5 \mathrm{M}$ & - MoH, Lao PDR \\
\hline & & & & & - EDCF \\
\hline & & & & & - KOICA \\
\hline & & Diagnosis and Quarantine System Building Project for Communicable & $2019-2023$ & $3 \mathrm{M}$ & - MoH, Lao PDR \\
\hline & & Disease Control in Lao PDR & & & $-\mathrm{KT}$ \\
\hline & Mongolia & Operation and Management Consulting for the Nuclear Medicine & 2015-2019 & $1.1 \mathrm{M}$ & - MoH, Mongolia \\
\hline & & Department of the National Diagnostic and Treatment Center in Mongolia & & & - EDCF \\
\hline & Myanmar & $\begin{array}{l}\text { Primary Healthcare System Strengthening Project in Yangon Region, } \\
\text { Myanmar }\end{array}$ & 2014-2019 & $5.5 \mathrm{M}$ & - MoHS, Myanmar \\
\hline & Philippines & Post-management Project for Tuberculosis Control Capacity Building in & 2017-2019 & $0.3 \mathrm{M}$ & - DoH, Philippines \\
\hline & & Palawan, Philippines & & & - WHO/WPRO \\
\hline & & & & & - WHO Philippines \\
\hline & & Health Promotion in the Urban Poor Area in Metro Manila of the & 2019-2021 & $0.9 \mathrm{M}$ & - DoH, Philippines \\
\hline & & Philippines & & & - WHO/WPRO \\
\hline & & & & & - WHO Philippines \\
\hline & Sri Lanka & Strengthening Management System of Medical Equipment in Sri Lanka & 2019-2024 & $8.2 \mathrm{M}$ & - MoHNIM, Sri Lanka \\
\hline & & & & & - EDCF \\
\hline & & & & & - KOICA \\
\hline & Uzbekistan & Operation and Management Consulting for the National Children's & 2014-2019 & $3.6 \mathrm{M}$ & - MoH, Uzbekistan \\
\hline & & Hospital in Uzbekistan & & & - EDCF \\
\hline & & & & & - KOICA \\
\hline & & Emergency Medical Service System Strengthening Project in Uzbekistan & 2019-2023 & $2.9 \mathrm{M}$ & - MoH, Uzbekistan \\
\hline & & & & & - RSCEMC, Uzbekistan \\
\hline & & & & & - EDCF \\
\hline & Vietnam & $\begin{array}{l}\text { Operation and Management Consulting for Health Facilities and Medical } \\
\text { Equipment in Vietnam }\end{array}$ & 2019-2021 & $2.2 \mathrm{M}$ & $\begin{array}{l}\text { - Provincial DoH, Lao Cai, Yen Bai, Da Nang } \\
\text { - EDCF }\end{array}$ \\
\hline \multirow[t]{18}{*}{ Africa } & Ethiopia & $\begin{array}{l}\text { Maternal, Neonatal and Child Health Promotion and Policy Cooperation } \\
\text { on National Health Insurance Scheme in Ethiopia }\end{array}$ & 2014-2019 & $5.9 \mathrm{M}$ & - Federal MoH, Ethiopia \\
\hline & & Strengthening Management System of Medical Equipment in Ethiopia & $2015-2020$ & $4.8 \mathrm{M}$ & - Federal MoH, Ethiopia \\
\hline & Ghana & Maternal, Newborn and Child Health Promotion in Volta Region, Ghana, & $2019-2023$ & $8.2 \mathrm{M}$ & - MoH, Ghana \\
\hline & & Second phase & & & - KOICA \\
\hline & Kenya & Strengthening Health Information Management System in Kenya & 2017-2019 & $0.6 \mathrm{M}$ & - MoH, Kenya \\
\hline & & & & & - KEMSA, Kenya \\
\hline & & & & & - NHIF, Kenya \\
\hline & & & & & - KOICA \\
\hline & Mozambique & Operation and Management Consulting for the Quelimane Central & 2013-2019 & $1.7 \mathrm{M}$ & - MoH, Mozambique \\
\hline & & Hospital in Mozambique & & & - EDCF \\
\hline & Tanzania & Health System Strengthening Project Focused on RMNCH in Pwani & $2016-2021$ & $5.4 \mathrm{M}$ & - MoHCDGEC, Tanzania \\
\hline & & Province, Tanzania & & & - KOICA \\
\hline & & Operation and Management Consulting for the MUHAS Academic Medical & 2013-2019 & $2 \mathrm{M}$ & - MUHAS Academic Medical Centre \\
\hline & & Centre (MAMC) in Tanzania & & & - EDCF \\
\hline & & & & & - KOICA \\
\hline & Uganda & $\begin{array}{l}\text { Health System Strengthening Project Focused on Emergency Medical } \\
\text { Service in Uganda }\end{array}$ & 2017-2021 & $3.5 \mathrm{M}$ & - MoH, Uganda \\
\hline & & National Tuberculosis Control Capacity Building Project in Uganda & 2017-2021 & $1.2 \mathrm{M}$ & - MoH, Uganda \\
\hline & & & & & - NTRL, Uganda \\
\hline
\end{tabular}

$\mathrm{DoH}=$ Department of Health; EDCF = Economic Development Cooperation Fund; KEMSA = Kenya Medical Supplies Authority; KOFIH = Korea Foundation for

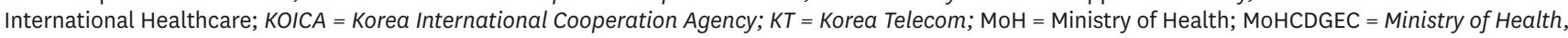
Community Development, Gender, Elderly and Children; MoHNIM = Ministry of Health, Nutrition \& Indigenous Medicine; MoHS = Ministry of Health and Sports; MUHAS = Muhimbili University of Health and Allied Sciences; NHIF = National Hospital Insurance Fund; NTRL = National Tuberculosis Reference Laboratory; RSCEMC $=$ Republican Scientific Center of Emergency Medical Care. 